\title{
Islamic Calendar Effect on Market Risk and Return Evidence from Islamic Countries
}

\author{
Akhter $\mathbf{A}^{1^{*}}$, Sandhu $\mathrm{A}^{2}$ and Butt $\mathrm{S}^{3}$ \\ ${ }^{1}$ PMAS-Arid Agriculture University Rawalpindi, PhD Scholar, Muhammad Ali Jinnah University, Islamabad, Pakistan \\ 2Jinnah Institute of Informatics Rawalpindi, Pakistan \\ ${ }^{3}$ Bahria University Islamabad, Pakistan
}

\begin{abstract}
Anomalies remain part of the market no matter it is developed or emerging one. Studies revealed that arbitragers materialize these situations and bring the markets back to efficiency. This study probed the presence of calendar anomalies in stock markets of six Islamic countries. It is empirically concluded that negative Zul-Hijjah effect presents in Malaysian stock market return and has no effect for other sample countries' stock markets. Zul-Hijjah has negative effect on the volatility of Turkish, Morocco and Egyptian stock markets and has no effect on the volatility of other sample countries' stock markets. Investors must consider this phenomenon while making decisions regarding investment and forming a diversified global portfolio. This field will help the investors in taking effective investment decision and for efficient resource allocation because knowledge of calendar anomalies plays a critical role to structure the optimal portfolio.
\end{abstract}

Keywords: Islamic Countries; Zul-Hijjah effect; Stock market return; Volatility

\section{Introduction}

Stock markets provide a platform where financer and borrower interact. In stock markets large number of sellers and buyers are endlessly occupied in trade of securities and stock markets report the progress of securities. Because the prices of securities move up and down depending on performance of companies and countries' economic and political conditions etc. Fama had worked upon informational efficiency and "Efficient Market Hypotheses" is based on the assumption that the prices of securities adjust quickly on the arrival of new information and existing prices completely reflect all available information.

"A market in which prices at any time fully reflect all available information is called efficient market". Finance literature, especially related to capital markets differentiates anomalies into three categories, namely calendar, technical and fundamental. Calendar anomalies mean abnormal behavior of stock markets at and during specific period of time. Calendar anomalies are one component among a number of factors of inefficient behavior of livestock markets [1]. The existence of anomalies criticizes the EMH presence. Gregorian calendar anomalies are investigated by many researchers. However, different communities follow their own religious calendars along with Gregorian calendar for their religious purposes as:

1. Jews follow their Hebrew calendar

2. Christians follow their Gregorian calendar

3. Muslims follow their Islamic calendar

There are different religious months and days in these religious calendars which are celebrated by these communities. Islamic calendar is followed by Muslims in more than fifty countries of the world and Muslims celebrate religious months such as Ramadan and Aashoora and days such as Eid-ul-Fitar and Eid-ul-Azha. The Islamic calendar is based on Hijri tied to lunar. It consists of 12 months according to 12 phases of the lunar.

In most of the previous studies Ramadan and Muharram effect was examined while Zul-Hijjah also most important month from religious point of view remain untested. Zul-Hijjah is the $12^{\text {th }}$ and last the month in Islamic calendar. The duration of first 10 days of Zul- Hijjah carries a great importance in Muslim culture. Hajj is performed in this month which is the fifth pillar of Islam. The $2^{\text {nd }}$ Muslim festival Eid-ulAzha falls on the $10^{\text {th }}$ of Zul-Hijjah and animals are sacrificed by the Muslims all over the world in the memory of Prophet Ibrahim (A.S). The month of Zul-Hijjah may negatively affect the stock markets of Muslim countries because of the fact that two major religious activities fall in this month that decrease the trading activities. The purpose of present study is to examine the effect of Zul-Hijjah on returns and volatility of six Islamic countries' stock markets indices. The countries of investigation are Pakistan, Malaysia, Indonesia, Turkey, Morocco and Egypt. Most recent time period for every sample Islamic country is used. This study contributes to the literature on market efficiency with respect to the sample Islamic countries.

The remaining paper is organized as: section 2 consists of review of related studies; section 3 explains the data and methodology, section 4 presents empirical results and section 5 summarizes and conclude the empirical results.

\section{Literature Review}

Efficiency of stock markets has been most discussed topic of researchers and EMH is most maligned in this regard. Calendar anomalies have been much discussed by researchers with respect to different stock markets for different periods since decades. In most of the world's stock markets Gregorian calendar anomalies were observed

*Corresponding author: Akhter A, Lecturer, PMAS-Arid Agriculture University Rawalpindi, PhD Scholar, Muhammad Ali Jinnah University, Islamabad, Pakistan, E-mail: uims.adnan@gmail.com

Received May 11, 2015; Accepted June 24, 2015; Published July 25, 2015

Citation: Akhter A, Sandhu A, Butt S (2015) PIslamic Calendar Effect on Market Risk and Return Evidence from Islamic Countries. J Bus Fin Aff 4: 140 doi:10.4172/2167-0234.1000140

Copyright: ( 2015 Akhter A, et al. This is an open-access article distributed under the terms of the Creative Commons Attribution License, which permits unrestricted use, distribution, and reproduction in any medium, provided the original author and source are credited. 
by many researchers. A review of notable literature on the topic of investigation is organized in the following section.

Aly, Mehdian and Perry [2] conducted a research for analyzing the day of the week effect in Islamic emerging Egyptian stock market for the period from 1998 to 2001 by using OLS. According to the results the Egyptian stock market (Capital Market Authority Index) was weakly efficient because Monday's returns were positive and significant but not significantly different from other trading days of week. Furthermore, Monday's higher returns were consistent with risk because Monday's returns standard deviation was also higher. A research for all index of Istanbul stock exchange for the period from 1987 to 2005 was conducted by Dicle and Hassan [3] for examining the day of the week effect by taking the closing values of both morning and afternoon secessions by employing AR and GARCH-M models the results showed that the day of the week effect existed. Higher returns were earned at the end of weak on Thursday and Friday while negative returns were observed on Monday.

Al-Khazali [4] investigated the day of week of effect in UAE stock markets for the period from 30 July 2001 to 30 August 2006 by using stochastic dominance approach because it was useful for making comparisons among distributions. The results indicated that the day of the weak effect was present in UAE stock markets and possible reason of this day of the weak effect was infrequent trading and illiquidity of stock markets otherwise UAE stock markets were efficient. Kamaly and Tooma [5] investigated the day of the week effect in 12 Islamic emerging stock markets (Egypt, Jordan, Kuwait, Dubai, Bhrain, Labanon, Morocco, Oman, Palestine, Qatar, Saudi Arab and Abu Dhabi) by using daily closing values of Monetary Fund index of the period from 2002 to 2005 by using AR and GARCH methodology. The results indicated that the higher returns were earned at starting and ending days of the week. A significant day of week effect on volatility also was observed in ten countries (Egypt, Jordan, Kuwait, Bhrain, Labanon, Morocco, Oman, Palestine, Qatar and Saudi Arab) at starting and ending days of the week.

Malaysian stock market was affected by financial crisis, and a research in this respect was held by Chia, Liew and Wafa [6] by taking Bursa Malaysia Composite index as a Malaysian stock market proxy covering the period from 1993 to 2005 by using GARCH model. The results were in contract to the results of previous researches January effect was not detected in Malaysian stock market. So, investors must purchase and held not sell the securities to get normal profit in long run and on the other hand they could get more profit than normal profit in short run by getting the benefit of misleading prices of securities. Al-Deehani [7] investigated the month of the year effect in Kuwait stock market covering the period of eight years from 1994 to 2004 by applying structural time series model. According to the results April and June effect was observed in Kuwait stock market and most of its sectors for the studied period due to summer holidays. Most of the people of Kuwait move toward cool countries to spend summer holidays and before leaving the country investors trade heavily due to which prices move upward. For the past seven years negative November effect had also been observed because of overlapping of Ramadan. During Ramadan trading activities might become slow.

Iran is an Islamic country and Tehran stock exchange is its major stock market. Nazari and AkbariRad [8] conducted a research for Tehran stock exchange for testing the "Weak form Efficiency Hypotheses" covering the period of eight years from 2002 to 2009 by using regression model. According to the results Tehran stock exchange was an inefficient stock market because calendar effect was examined for returns (Positive Jun effect), trade volume (Negative September, April and August effect) and volatility (Positive August effect). Moreover calendar effect was also observed for the returns of 21 industries out of 37 industries.

Cultural and religious festivals play an important role in the financial markets in increase and decrease regarding returns on investment in different stock markets. According to Al-Ississ [9] there are two reasons due to which equity markets are affected by cultural and religious festivals. First, on religious and cultural festivals' days the followers of a particular religion become absent from stock markets. The impact of their absence can cause a single sided effect if they all have the same attitude towards the investment decisions or have no effect if they differ in investment point of view. Second, the mood of investors is a function of religious events which affects the investment decisions.

Georgian calendar was extremely focused by researchers for the study of behavior of stock markets. A few numbers of studies were conducted to study the impact of Islamic calendar anomalies on stock markets of Islamic countries by some researchers Seyyed, Abraham and Al-Hajji [10], Ariss, Rezvanian and Mehdian [11], Bialkowski, Etebari and Wisniewski, Al-Hajieh, Redhead and Rodgers [12] and Husain [13]. The purpose of this research is to examine the behavior of stock markets of Islamic countries according to Islamic calendar (which is based on the phases of moon) events such as Muharram, Ramadan and Zul-Hijjah.

Pakistani equity market was examined by Husain [13] for the period from 1989 to 1993 to examine the Islamic month of year effect by applying GARCH model. The results of this study showed that during the holy month of Ramadan the returns of securities remained same but volatility decreased may be due to slow economic activity and reduced working hours during the Holy month of Ramadan. Seyyed, Abraham and Al-Hajji [10] examined Ramadan effect in Saudi stock market for the period from 1985 to 2000 by employing GARCH model. The results indicated that weekly returns of Saudi stock market during the Holy month of Ramadan were same as the returns during other months but volatility moved downward might be due to low trading activity or change in investor's attitudes. A number of factors contribute to change in investors attitudes such as reduced working hours and absence of investors from stock market for the performance of religious duties.

Al-Hajieh, Redhead and Rodgers [12] examined the Ramadan effect on return and volatility of Islamic Middle Eastern stock markets covering the period from 1992 to 2007 through Runs test. The results of that study were in line of results of previous studies as positive association of Ramadan and returns but in contract to the results of previous studies positive association of Ramadan with Volatility was detected in Middle Eastern countries' (Bahrain, Egypt, Jordan, Kuwait, Saudi and Turkey) equity markets especially at starting and ending days of Ramadan. Ariss, Rezvanian and Mehdian [11] examined the day of weak and Islamic month of year effect for Gulf Cooperation Council stock markets for the period from 1994 to 2008 by using OLS. The results indicated that like western stock markets Gulf Cooperation Council stock markets showed last working day effect (Wednesday Effect). So, the foreign investors could earn abnormal return on Monday in Gulf Cooperation Council stock markets because it is not first working day in these stock markets. No Islamic month of year effect was present but volatility decreased during the Holy month of Ramadan.

Mustafa [14] examined the Karachi stock market for the period of from 1998 to 2004 by using conditional and unconditional models the 
results indicated that the returns during Holy month of Ramadan are lower as compared to Ziqad and Shawal because these two months come after the Ramadan. The people may spent money on purchasing new clothes and shoes to celebrate the Eid-ul-fater and did not concentrate on investment in equity market during Ramadan. Bialkowski, Etebari and Wisniewski explored the relationship between Ramadan and stock market returns and volatility of 14 Islamic countries' (Bahrain, Egypt, Indonesia, Jordan, Kuwait, Malaysia, Morocco, Pakistan, Qatar, Saudi Arabia, Tunisa, Oman, Turkey and United Arab Emirates) stock markets covering the period from 1989 to 2007 through event study. The results indicated positive association of Ramadan and returns of stock markets of Islamic countries and negative association of Ramadan with volatility of sample countries' stock markets may be due to positive social attitude of investors during Ramadan which was reflected in their investment decisions.

Gowan and Jakob [15] examined the Malaysian stock market to check Eid-ul-Fitar effect for the period from 2000 to 2003 by employing OLS. The results showed that Eid-ul-Fitar effect was not found but Chinese New year effect was detected. The possible reason of such results was population of Chinese investors is higher than Muslims investors and the amount of cash bonuses granted by organizations at the event of Eid-ul-fiter is less than the amount of those bonuses which are given for the celebration of Chinese New year due to these reasons Malaysia's stock market shows Chinese New year effect.

By reviewing the literature, it has been concluded that stock market returns and volatility do not remain constant. It means that some abnormalities exist somewhere in stock markets such as Monday effect, January effect and holiday effect etc. Cultural and religious festivals also have effect on stock market returns and volatility reviewed in literature such as Chinese Spring Festival and Ramadan effect etc. The present study focuses on exploring the effect of Zul-Hijjah on returns and volatility of stock markets of Islamic countries.

\section{Methodology}

Six pure Islamic countries selected for the study to investigate the impact of the Islamic month on risk and return of the stock market. The details of selected stock markets with sample time period are elaborated in Table 1.

The stock market return is calculated with the help of following formula.

$$
\begin{aligned}
& \mathrm{SMR}_{\mathrm{i}, \mathrm{t}}=\ln \left(\mathrm{Cv}_{\mathrm{i}, \mathrm{t}} / \mathrm{Cv}_{\mathrm{it}-1}\right) \\
& \text { Where } \\
& \mathrm{SMR}_{\mathrm{i}, \mathrm{t}}=\text { stock market return at day t of } \mathrm{i} \text { index. } \\
& \mathrm{Cv}_{\mathrm{i}, \mathrm{t}}=\text { closing value at day } \mathrm{t} \text { of index } \mathrm{i} . \\
& \mathrm{Cv}_{\mathrm{i}, \mathrm{t}-1}=\text { closing value at day } \mathrm{t}-1 \text { of index } \mathrm{i} .
\end{aligned}
$$

A software Calendar Convertor is used for the conversion of Georgian dates to respective Hijjari Calendar dates which may arise to one day error because the beginning of every Hijjari month depending on moon sighting which may be different for different countries by the difference of one day. To study the impact of the Zul-Hijjah on return and volatility of stock markets of Islamic countries Autoregressive Conditionally Heteroscedastic Model has been chosen due to the reason that that assumption of the linear regression model that the variance of the errors is constant over time is violated in our case. If the variance of the errors over time is not constant, an implication would be that standard error estimates can be wrong [16]. In the context of financial time series and prices of securities the variance is not constant that makes sense to consider a model which does not assume that the variance is constant. The most suitable model for such series is GARCH for forecasting volatility because it also includes the lag values of variables.

GARCH $(1,1)$ Model is used to capture the effects of Zul-Hijjah on stock market return and volatility of Islamic Countries. In order to approximate and quantify the effect, we have constructed index which summarize variable for capturing the impact of Zul-Hijjah for the stock markets of Islamic Countries. The index was constructed to capture the effect of zul-hijjah through dummy variable as;

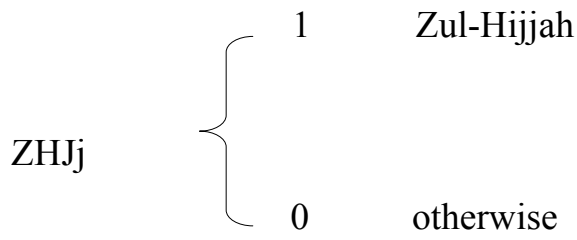

$R_{t}=\beta_{0}+\beta_{1} R_{t-1}+\beta_{2} Z H J$

The mean equation shows that return is a function of lag return.

Where as

$\mathrm{R}_{\mathrm{t}}=$ today return

$\mathrm{R}_{\mathrm{t}-1}=$ return of the previous day

$\mathrm{ZHJ}=$ the dummy variable for Islamic Month of Zul-Hajj

$$
\sigma^{2}=r_{0}+r_{1} U_{t-1}^{2}+r_{2} \sigma_{t-1}^{2}+r_{3} Z H J
$$

Where as

$\sigma^{2}=$ today's volatility

\begin{tabular}{|c|c|c|c|c|c|}
\hline Sr. No. & Countries & Indexes & $\begin{array}{l}\text { Index } \\
\text { Symbol }\end{array}$ & $\begin{array}{l}\text { Time } \\
\text { Period }\end{array}$ & $\begin{array}{c}\text { No. of } \\
\text { Observations }\end{array}$ \\
\hline 1 & Pakistan & $\begin{array}{l}\text { KSE } 100 \\
\text { Index }\end{array}$ & KSE & $\begin{array}{c}7 / 1 / 1997 \text { to } \\
5 / 3 / 2013\end{array}$ & 3863 \\
\hline 2 & Malaysia & $\begin{array}{c}\text { FTSE } \\
\text { Bursa } \\
\text { Malaysia } \\
\text { KLSI }\end{array}$ & KLSE & $\begin{array}{c}7 / 1 / 1997 \text { to } \\
5 / 3 / 2013\end{array}$ & 3909 \\
\hline 3 & Indonesia & $\begin{array}{l}\text { Composite } \\
\text { Index }\end{array}$ & JKSE & $\begin{array}{c}7 / 1 / 1997 \text { to } \\
5 / 3 / 2013\end{array}$ & 3851 \\
\hline 4 & Turkey & $\begin{array}{c}\text { Istanbul } \\
\text { National } \\
100 \text { Index }\end{array}$ & XU 100 & $\begin{array}{c}12 / 4 / 2006 \\
\text { to } \\
4 / 30 / 2013\end{array}$ & 1645 \\
\hline 5 & Morocco & $\begin{array}{l}\text { Dow Jones } \\
\text { Morocco } \\
\text { Total Stock } \\
\text { Market } \\
\text { Index MAD }\end{array}$ & DWMA & $\begin{array}{l}12 / 4 / 2006 \\
\text { to } \\
4 / 30 / 2013\end{array}$ & 1665 \\
\hline 6 & Egypt & $\begin{array}{l}\text { Dow Jones } \\
\text { Egypt } \\
\text { Total Stock } \\
\text { Market } \\
\text { Index EGP }\end{array}$ & DWEG & $\begin{array}{c}12 / 4 / 2006 \\
\text { to } \\
4 / 30 / 2013\end{array}$ & 1479 \\
\hline
\end{tabular}

$\sigma_{t-1}^{2}+r_{1}=$ previous day's volatility this is GARCH term.

$U_{t-1}^{2}=$ Previous day's volatility this is ARCH term.

$\mathrm{ZHJ}=$ the Islamic Month of Zul-Hajj

\section{Results}

The test results of the ARCH effect are reported in Table 2. The

Table 1: details of selected stock markets with sample time period. 
p-value of $\mathrm{Obs}^{\star} \mathrm{R}$-square for all sample Islamic countries is less than 0.05 . So, ARCH effect exists in return series of all sample Islamic countries. Therefore, the Null Hypothesis of no Heteroskedasticity is rejected and can proceed with Generalized Auto Regressive Heteroskedasticity Model.

\section{Zul-Hijjah effect on stock market's returns}

The results of mean equation are reported in following Table 3. The intercept $\mathrm{C}$ shows the average returns of sample Islamic countries stock markets. Higher average return (0.001141) was observed for Indonesian stock market and negative return (-0.00267) was observed for Morocco stock market. The autoregressive term for Pakistani, Malaysian, Indonesian and Turkish stock markets is significant which implies that today's returns depend on previous day's returns. The positive coefficient in case of Pakistani, Malaysian, and Indonesian stock markets show that today's returns are more than previous day's returns. In case of Turkish stock market negative coefficient implies that today's return is less than yesterday's return. For Morocco and Egyptian stock markets the autoregressive term is insignificant which means today's returns have no influence of yesterday's returns. This is a classic case of "Random Walk" and "Weak Form Efficiency Hypotheses" that hold true here specifically for stated countries.

The coefficient of dummy variable of $\mathrm{ZHJ}$ for the holy month of Zul-Hijjah is statically insignificant for five sample countries (Pakistan, Indonesia, Turkey, Morocco and Egypt) stock market which means that the returns of these countries stock markets are not affected due to the holy month of Zul-Hijjah. In case of Malaysian stock market the coefficient of dummy variable ZHJ for the holy month of Zul-Hijjah is statically significant. This shows that the return of Malaysian stock market is affected due to the holy month of Zul-Hijjah. The coefficient is negative which implies that the holy month of Zul-Hijjah causes decline in return of Malaysian stock market. The negative Zul-Hijjah effect in Malaysian stock market may appear due to low trading activity during this month. It can be said that due to religious month, investors liquidate their positions to perform their religious duties specifically in that month.

\section{Zul-Hijjah effect on stock market's volatility}

The results of variance equation are reported in following Table 4. The coefficient of lagged squared residual is significant for Pakistani, Malaysian, Indonesian and Turkish stock markets which means that previous price behavior prevails in today's volatility. The positive coefficient implies that today's volatility is more than previous volatility. In case of Morocco and Egyptian stock markets the coefficient of lagged squared residual is insignificant which means that previous price behavior has no influence on today's volatility. The $p$ value of lagged conditional variance term in the conditional variance equation is statistically significant for Pakistani, Malaysian, Indonesian, Turkish and Morocco stock markets which means today's volatility depends on previous day's volatility and coefficient is positive which means

\begin{tabular}{|c|c|c|c|}
\hline Country & Index & $\begin{array}{c}\text { Observed } \\
\text { Square }\end{array}$ & P Value \\
\hline Pakistan & KSE 100 & 192.7280 & 0.0000 \\
\hline Malaysia & FTSE & 956.6604 & 0.0000 \\
\hline Indonesia & Composite & 129.1784 & 0.0000 \\
\hline Turkey & IN 100 & 127.9352 & 0.0000 \\
\hline Morocco & DJ MAD & 136.6522 & 0.0000 \\
\hline Egypt & DJ EGP & 134.2281 & 0.0000 \\
\hline
\end{tabular}

Table 2: test results of the $\mathrm{ARCH}$ effect. today's volatility is more than previous volatility. In case of Egyptian stock market the coefficient of lagged conditional variance term in the conditional variance equation is statistically insignificant which means today's volatility does not depend on previous day's volatility.

The coefficient of $\mathrm{ZHJ}$ is significant for three sample countries (Turkey, Morocco and Egypt) stock markets this shows that the volatility of these countries stock markets is affected due to the holy month of Zul-Hijjah. The coefficient is negative for these sample countries (Turkey, Morocco and Egypt) stock market which means that volatility decreases during the holy month of Zul-Hijjah. The dummy variable $\mathrm{ZHJ}$ is insignificant for three sample countries (Pakistan, Malaysia and Indonesia) stock market which implies that the volatility of these countries' stock markets is not affected by the holy month of Zul-Hijjah. The possible reason of negative Zul-Hijjah effect on volatility is low trading in market. And it can also be concluded that arbitrageurs in this month help market to achieve efficiency which reduces the market volatility and almost market is at its fundamental.

\section{Conclusion}

The objective of the study was to investigate the impact of Zul-Hijjah on stock market return and volatility of the Islamic countries. For this purpose six countries (Pakistan, Turkey, Indonesia, Malaysia, Egypt and Morocco) are selected. In most of the previous studies Muharram and Ramadan effect was examined while Zul-Hijjah is also most important from religious point of view. For the purpose to examine the impact of Zul-Hijjah on return and volatility of Islamic countries' stock markets daily closing values of selected Islamic countries' stock markets indices were taken.

GARCH $(1,1)$ Model is used for capturing the impact of Zul-Hijjah on return and volatility of stock markets of selected Islamic countries. The results reveal that Zul-Hijjah has negative effect only for the Malaysian stock market return and has no effect on the Pakistani, the Indonesian, the Turkish, the Morocco and the Egyptian stock market return. This shows that Malaysian society is devoted Islamic society and members of Malaysian society are less actively involved in corporeal pursuits and spent more and more time in prayers during this holy month. It is obvious that Malaysian society is closer to the Islamic practices.

In case of volatility negative Zul-Hijjah effect exists for the Turkish, the Morocco and the Egyptian stock market. There may be a religious furor in these countries and investors focus on religious duties and avoid from speculation which is prohibited in Islam due to which volatility moves downward. Zul-Hijjah has no effect on volatility in the Malaysian, the Pakistani and the Indonesian stock market. In Pakistani and Indonesian stock markets Zul-Hijjah has no effect on return and volatility this shows that everything goes on as usual during the month of Zul-Hijjah as it is before. These societies may be in process of change where people are getting away from religious practices and only paying lip service to Islam.

It is beneficial for the investors of sample Islamic countries, to invest in Pakistani stock market because Morgan Stanley declared Pakistan market as the most attractive market across the Asian markets. And we have also seen that the average return of the Pakistani stock market is 0.0011 which is slightly less than the average return 0.001141 of the Indonesian stock market but higher than the other stock markets. The coefficient of dummy variables ZHJ for the holy months of Zul-Hijjah in mean equation is negative for all sample Islamic countries except the Pakistani and Morocco stock markets. 
Citation: Akhter A, Sandhu A, Butt S (2015) PIslamic Calendar Effect on Market Risk and Return Evidence from Islamic Countries. J Bus Fin Aff 4: 140. doi: $10.4172 / 2167-0234.1000140$

Page 5 of 5

\begin{tabular}{|c|c|c|c|c|c|c|}
\hline & $\begin{array}{l}\text { Pakistan } \\
\text { KSE } 100\end{array}$ & $\begin{array}{c}\text { Malaysia } \\
\text { FTSE }\end{array}$ & $\begin{array}{l}\text { Indonesia } \\
\text { Composite }\end{array}$ & $\begin{array}{l}\text { Turkey } \\
\text { IN } 100\end{array}$ & $\begin{array}{l}\text { Morocco } \\
\text { DJ MAD }\end{array}$ & $\begin{array}{c}\text { Egypt } \\
\text { DJ EGP }\end{array}$ \\
\hline C & 0.0011 & 1.46E-05 & 0.001141 & 0.000512 & -0.00267 & 0.00902 \\
\hline $\operatorname{Ar}(1)$ & 0.0614 & 0.145176 & 0.116619 & -0.48877 & -0.03283 & -0.0346 \\
\hline P Value & 0.0004 & 0.0000 & 0.0000 & 0.0000 & 0.9405 & 0.9004 \\
\hline ZHJ & 0.000199 & -0.00135 & -0.00046 & -0.01053 & 0.002465 & -0.0024 \\
\hline P Value & 0.7806 & 0.0005 & 0.6149 & 0.8859 & 0.9601 & 0.9505 \\
\hline
\end{tabular}

Table 3: results of mean equation.

\begin{tabular}{|c|c|c|c|c|c|c|}
\hline & $\begin{array}{l}\text { Pakistan } \\
\text { KSE } 100\end{array}$ & $\begin{array}{c}\text { Malaysia } \\
\text { FTSE }\end{array}$ & $\begin{array}{l}\text { Indonesia } \\
\text { Composite }\end{array}$ & $\begin{array}{l}\text { Turkey } \\
\text { IN } 100\end{array}$ & $\begin{array}{l}\text { Morocco } \\
\text { DJ MAD }\end{array}$ & $\begin{array}{c}\text { Egypt } \\
\text { DJ EGP }\end{array}$ \\
\hline C & 7.26E-06 & $1.65 \mathrm{E}-06$ & $6.03 \mathrm{E}-06$ & 0.001124 & 0.002511 & 0.003517 \\
\hline$\left(\operatorname{Resid}_{t-1}\right)^{2}$ & 0.16491 & 0.219789 & 0.132395 & 0.02667 & 0.064989 & 0.062855 \\
\hline P Value & 0.0000 & 0.0000 & 0.0000 & 0.0001 & 0.3619 & 0.1240 \\
\hline GARCH(-1) & 0.81607 & 0.822768 & 0.854766 & 0.789794 & 0.461452 & 0.354053 \\
\hline P Value & 0.0000 & 0.0000 & 0.0000 & 0.0000 & 0.0186 & 0.0622 \\
\hline $\mathrm{ZHJ}$ & $-2.67 \mathrm{E}-07$ & 7.83E-07 & $1.55 \mathrm{E}-06$ & -0.00140 & -0.008353 & -0.005694 \\
\hline P Value & 0.9116 & 0.1075 & 0.2438 & 0.00000 & 0.0000 & 0.0000 \\
\hline
\end{tabular}

Table 4: results of variance equation.

\section{References}

1. Abu-Rub N, Sharba T (2011) Calendar effects in the Palestine securities exchange analysis and investigation. World Review of Business Research 1: $52-66$.

2. Alya H, Mehdian S, Perry MJ (2004) An analysis of day of the week effect in the Egyptian stock market. International Journal of Business 9: 301-308.

3. Dicle MF, Hassan MK (2007) Day of the Week Effect in Istanbul Stock Exchange. Scientific Journal of Administrative Development 5

4. Al-Khazali OM (2008) The Impact of Thin Trading on Day of the Week Effect: Evidence from United Arab Emirates. Review of Accounting and Finance 7 270-284.

5. Kamaly A, Tooma EA (2009) Calendar anomalies and stock market Volatility in selected Arab stock exchanges.Applied Financial Economics 19: 881-892.

6. Chia RJ, Liew VK, Wafa SAWSK (2006) Calendar anomalies in the Malaysian stock market. Munich Personal RePEc Archive. 516.

7. Al-Deehani TM (2006) Seasonality as an unobservable component: The case of Kuwait stock market. Applied Financial Economics 16: 471-478.

8. Nazari M, AkbariRad M (2011) Analysis and Diagnosis of Calendar Effect in Tehran Stock Exchange. Journal of Basic and Applied Scientific Research 1 854-862.
9. Al-Ississ M (2010) The Impact of Religious Experience on Financial Markets. Working Paper.

10. Seyyed FJ, Abraham A, Al-Hajii M (2005) Seasonality in stock returns and volatility: The Ramadan effect. Research in International Business and Finance 19: $347-383$

11. Ariss RT, Rezvanian R, Mehdian S (2011) Calendar anomalies in the Gulf Cooperation Council stock markets. Emerging markets review 12: 293-307.

12. Al-HajiehH, Redhead K Rodgers T (2011) Investor Sentiment and Calendar Anomaly Effects: A Case Study of the Impact of Ramadan on Islamic Middle Eastern Markets. Research in International Business and Finance 25: 345-356.

13. Husain F (1998) Seasonality in the Pakistani Equity Market: The Ramadhan Effect. The Pakistan Development Review 37: 77-81.

14. Mustafa K (2011) The Islamic calendar effect on Karachi stock market. Global Business Review 13: 562-574.

15. McGowan CB, Jakob NA (2010) Is there an Eid-Ul-Fitr Effect in Malaysia? International Business and Economic Research Journal 9: 11-19.

16. Gujarati D (2003) Basic Econometrics Fourth (4thEdn). McGraw-Hill. 